\title{
The definition of «capital» as an economic and accounting category
}

\author{
Oksana Butkova ${ }^{1, *}$ \\ ${ }^{1}$ Azov-Black Sea Engineering Institute, Don State Agrarian University, 21, Lenina str., 347740, \\ Zernograd, Russia
}

\begin{abstract}
The definition of «capital» has attracted and continues to attract the attention of researchers of the international scientific community, since any economic entity revolving in the economic space should possess certain capital and be clearly aware of what goals it needs to be invested at a specific point in time. With the advancement of science new economic categories have appeared, which are integral part of the conceptual definition of «capital». In this regard, due to the novelty of some components of the capital for the Russian economy, differences arise in the interpretation of the concept and, as a result, its incorrect use in the practical activities of Russian economic entities. Through research there has been revealed that the term content of the definition of «capital» as an economic and accounting category has been changing along with the evolutionary process of economic knowledge. The article systematizes the views on the concept of «capital» from the perspective of economic theory and accounting. The relationship between the components of the definition of «capital» is highlighted. Author's definitions of the components of «capital» within the system of the accounting and analytical system of an economic entity are proposed.
\end{abstract}

\section{Introduction}

In today's modern economic reality, characterized by a high level of instability, the search problem of sources of financing for their statutory activities is quite urgent for most domestic economic entities. Due to the fact that the economic uncertainty of the economic conditions set the task for economic entities to improve performance, and increased responsibility for the results of economic activities of enterprises before the leaders of all levels.

First of all, the adoption of effective management decisions requires enterprise management to have a clear idea of the sources through which an economic entity intends to carry out its statutory activities. Therefore, any organization working separately from other economic entities, engaging in industrial or other commercial activities, should have certain capital and be clearly aware in which areas of activity it should be directed. And the enterprise management should remember that the financial condition of the economic entity

\footnotetext{
* Corresponding author: butkova_ov@inbox.ru
} 
depends on the transfer of capital into non-current and current assets, as well as on the structure of capital.

\section{Main part}

The capital structure is important for the successful functioning of an enterprise, since each of the components of capital has a certain function in the implementation of the production activities of an economic entity [1].

Fundamental changes in the external environment of an enterprise, the need for an adaptability to them make it necessary to study the definition of «capital», which is one of the key, fundamental and rather complex economic concepts.

The definition of «capital» comes from the Latin word «capital» - is main, principal, and is one of the most studied and at the same time the most complex and confusing economic categories. The nature of the definition of «capital» has been studied by the scientific community for several centuries, but even today scientists have not reached agreement on its term content.

In the current Russian science realities, the term content of the definition of «capital» and its components, borrowed from foreign experience, is used. In this regard, due to the novelty of some components of capital for the Russian economy, differences arise in the interpretation of concepts and, as a result, their incorrect use in the practical activities of Russian economic entities. Therefore, the purpose of the research is to study the definition of «capital» in the historical development of both economic and accounting categories, as well as its components, to summarize scientific knowledge and formulate these categories that meet the modern conditions of Russian economic science.

In the study of the definition of «capital» the following learning methods were used: analysis, synthesis, concretization and abstraction, classification, grouping, and others.

As a rule, all studies related to accounting begin with a consideration of the economic nature of its objects, with an analysis of the interpretations of various schools of economic theory.

The nature and structure of capital directly depend on the evolution of the development of economic doctrines. Over the course of economic science history, two conceptual approaches arose to determine the nature of capital and its structure - an economic approach and an accounting one.

Due to the fact that general economic theory is a decisive factor in cognizing the nature of economic processes, and the object of its study is property relations, therefore capital initially became the object of research by economists (Table 1).

Table 1. Systematization of the definition of «capital» from the perspective of economic theory.

\begin{tabular}{|l|l|l|}
\hline \multicolumn{1}{|c|}{ Economic school } & Representatives & \multicolumn{1}{c|}{ Interpretation of capital } \\
\hline Mercantile system & W. Stafford & Capital is identified with money, wealth. \\
\hline Physiocratism & F. Quesnay & $\begin{array}{l}\text { The category, used in the production, is divided into } \\
\text { working and fixed capital. }\end{array}$ \\
\hline \multirow{2}{*}{ Classicism } & A. Smith & Accumulation of wealth with the help of wage labour. \\
\cline { 2 - 4 } & D. Ricardo & Capital is identified with means of production. \\
\hline Marxism & K. Marx & $\begin{array}{l}\text { Growth of wealth, surplus value, formed by the labour } \\
\text { of employees. }\end{array}$ \\
\hline \multirow{2}{*}{ Neoclassicism } & A. Marshall & $\begin{array}{l}\text { An element of wealth, bringing its owner a regular } \\
\text { income for a long time. }\end{array}$ \\
\cline { 2 - 4 } & I. Fisher & Capital is related to discounted income. \\
\hline
\end{tabular}


The category «capital» is first found in the works of mercantilists. The most prominent representative of this school is W. Stafford. Mercantilists identified capital either with precious metals and coins made from them, or with goods that will turn into money in the near future, that is, the term «capital» was associated with a certain type of wealth.

In the second half of the 18th century there appeared a physiocratic doctrine, the founder of which is considered to be F. Quesnay. The representatives of this economic school believed that capital is material, that is, it is used in production and is divided into working and fixed capital.

A. Smith being the founder of the classical economic school substantiated the principles of the emergence, formation and further functioning of capital, characterizing the latter as accumulated wealth through using wage labor. D. Riccardo relying on A. Smith's works substantiated the principles of redistribution of capital and interpreted the latter as a means of production.

A systematic approach to the study of capital as an economic category is reflected in the works of K. Marx, who considered capital as a social category creating added value. In his works K. Marx showed the process of reproduction of capital and its dynamic nature. It was $\mathrm{K}$. Marx who characterized capital as a relationship between business entities, as well as self-expanding value.

The supporters of the neoclassical economic school (A. Marshall, J.S. Mil, J.-B, Say, I. Fisher and others) interpreted capital as an element of wealth, bringing its owner regular income for a long time. I. Fisher defines capital as «discounted income».

The analysis of the historical genesis of the definition of «capital» allowed us to identify three main approaches to determining its nature within the accounting and registration and analytical system of an economic entity.

The authors of the first approach associate the value of the net assets of the economic entity with the capital, that is, one assumes that capital is the total value of the assets of an enterprise with the deduction of its liabilities formed as a result of using fixed and working capital.

The representatives of the second approach consider the term «capital» as an entire stock of enterprise assets necessary for the implementation of the production process aimed at the formation of material wealth.

The followers of the third approach believe that capital is a combination of equity and loan capital necessary for the implementation of the statutory activity of an enterprise.

Analyzing the works of prominent economists, it can be noted that there is a certain difference in the terminology of capital in both a financial and physical structure. Moreover, it should be noted that the correlation of capital with the financial activity has not been appreciated yet [2]. Nevertheless, despite the apparent differences in the interpretation of capital, all researchers associate capital with any resources generating income.

The development of economic science entailed further research of the definition of «capital» by foreign scientists. At the end of the 20th century, the division of capital into components continued, which led to the emergence of new components of the definition of «capital»: natural, human, social, intellectual and information capital.

The concept of natural capital has recently been of great interest [3] not only to economists, but to the entire world scientific community. Natural capital represents the environment: representatives of flora and fauna, as well as their waste products that affect the activity of economic entities. The concept of natural capital is intended to include the environment in narrow economic appraisals $[4,5]$. It should be noted that today the natural capital appreciation is still focused on the estimate of proceeds of their use, rather than on the cost estimate of its conservation. 
Human capital is a combination of accumulated knowledge and experience of economic entities. Studies conducted by foreign scientists on the definition of «human capital» showed that education, professional experience, and also the gender of members of a team of an economic entity can influence not only profit margin, but also the number of attracted investors [6]. Studies have also proven the existence of causation relationships between human and natural capital [7].

Social capital is a diverse relationship between market participants and plays an important role in the competitiveness of the economic entity and its financial sustainability. The ability of social capital to adapt and respond to economic shocks [8, 9] has been proved, having a direct impact on the sustainability of an economic entity. Through research, it was proved that in most cases social capital has a positive effect on the growth of economic entities [10].

Perhaps the most controversial definition in the economics is «intellectual capital», which is a combination of certain knowledge and skills aimed at using the potential of research and development work that arose with the active development of scientific and technological progress to obtain economic benefits for the enterprise. Studies of intellectual capital have shown that the total IQ of a company has a direct impact on its productivity [11] and the size of financial indicators [12], while operating indicators directly depend on the age of employees, their intelligence, as well as on the level of remuneration for their work [13].

The rapid development of the scientific and technical potential of economic entities entailed the emergence of the definition of «information capital» as an economic category. Information capital is meant to be a set of information that directly affects the amount of financial flows. It is revealed that information capital is closely connected with both human and intellectual capital and is their integral part.

The economic growth characteristic of the beginning of the 19th century led to the dynamic development of industry, trade relations, and an increase in labor productivity. These are these components that stimulated the development of accounting as a science.

Capital throughout the ages has been one of the most important objects of accounting, since it gives an idea of the scale of an enterprise, the possibilities of its development, as well as the financial situation of an economic entity.

Both in economic theory and accounting there has also been a study of the definition of «capital». Research scientists were seeking to provide the category of «capital» with a comprehensive description as an accounting category, as an object of accounting reflected on a specific account [14].

Before the introduction of double entry, the concept of «capital» in accounting was either not considered at all, or was identified with money, wealth.

The appearance of Capital account was the basis for the emergence of double-entry bookkeeping and made it possible to distinguish between an enterprise and its owner as autonomous entities. Due to the differences in the interpretation of the term content of «capital», the use of this account in accounting was also different, which was expressed in the productivity of differentiation between the capital accounting and its owner.

With the development of accounting as a science there has emerged a separate group of accounts including Capital account and all the income and expenditure accounts. However, with a new stage of development, the definition of «capital» was considered by scientists from different positions [15] (Table 2). 
Table 2. Systematization of approaches to the terminology of the category «capital» from the perspective of the development of accounting.

\begin{tabular}{|l|l|l|}
\hline $\begin{array}{c}\text { Type of } \\
\text { accounting }\end{array}$ & \multicolumn{1}{|c|}{ Representatives } & \multicolumn{1}{c|}{ Capital } \\
\hline Cameral & B. Cotrugli, L. Pacioli & $\begin{array}{l}\text { It is identified with the concept of financial results, in } \\
\text { particular with realization of profit when expenditure } \\
\text { exceeded income of an entity. }\end{array}$ \\
\hline Statistical & I.F. Sherr & It is considered in terms of net assets of an enterprise \\
\hline Dynamic & H. Schmalenbach & $\begin{array}{l}\text { It is compared with the funding of an enterprise, } \\
\text { formed at the expense of own and loan funds, and it } \\
\text { is considered from the point of view of profitability }\end{array}$ \\
\hline Adaptive & $\begin{array}{l}\text { D.A. Endovitsky, } \\
\text { E.M. Evstafieva }\end{array}$ & $\begin{array}{l}\text { It is defined as a combination of equity and loan } \\
\text { capital formed by obtaining financial resources } \\
\text { adjusted for inflation. }\end{array}$ \\
\hline
\end{tabular}

The analysis of interpreting capital in modern national science and practice allows us to conclude that the definition of «capital» as an economic and accounting category takes place only in Accounting concept in the market economy of the Russian Federation "capital is the investment of owners and profit accumulated in all the time of the activity of an enterprise. The capital value is defined as the difference between the assets and liabilities of an economic entity» (Fig. 1). Therefore, in accordance with this legislative act, the capital of an economic entity is exclusively identified with its equity capital. In our opinion, such a definition of the definition of «capital» is extremely narrow and does not cover the modern achievements of science in this matter.

The principles of IFRS define capital as net assets, that is, as «the residual interest in the organization's assets after deducting all of its liabilities»».

Thus, the study showed that, in the evolution of economic science and accounting the interpretations of the definition of «capital» and the set of indicators characterizing it have changed. However, despite the duration and fundamental nature of research on the definition of «capital» of both economic and accounting categories, researchers have not formulated so far by a universal definition of capital that would fully meet the needs of both theoretical and practical research in this area.

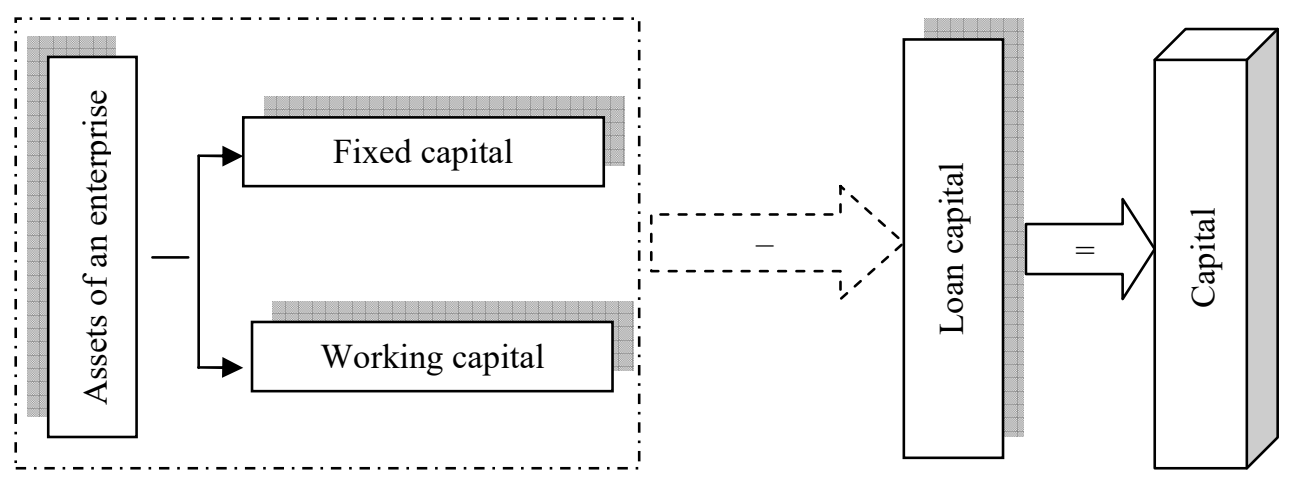

Fig. 1. Value of capital in accordance with Accounting concept in a market economy of the Russian Federation.

After analyzing the views of national and foreign scientists and taking into account the current level of scientific and technological progress, we proposed an author's definition of capital within the current integration and technological type of accounting, which stood out thanks to modern discoveries in the field of information technology. This type of accounting significantly expands the possibilities of accounting by itself, allowing us to 
integrate information not only about internal business processes of an economic entity, but also about external environment of its functioning into the accounting.

Within integration and technological accounting, capital is an economic resource that has been used for a long time and represents a unified system consisting of fixed, working, equity, loan, human and information capital. Cumulatively all the components of capital being at its disposal and possessing the ability to make a profit are necessary for the economic activity of an economic entity.

The relationship between the components of the definition of «capital» are presented in Fig. 2.

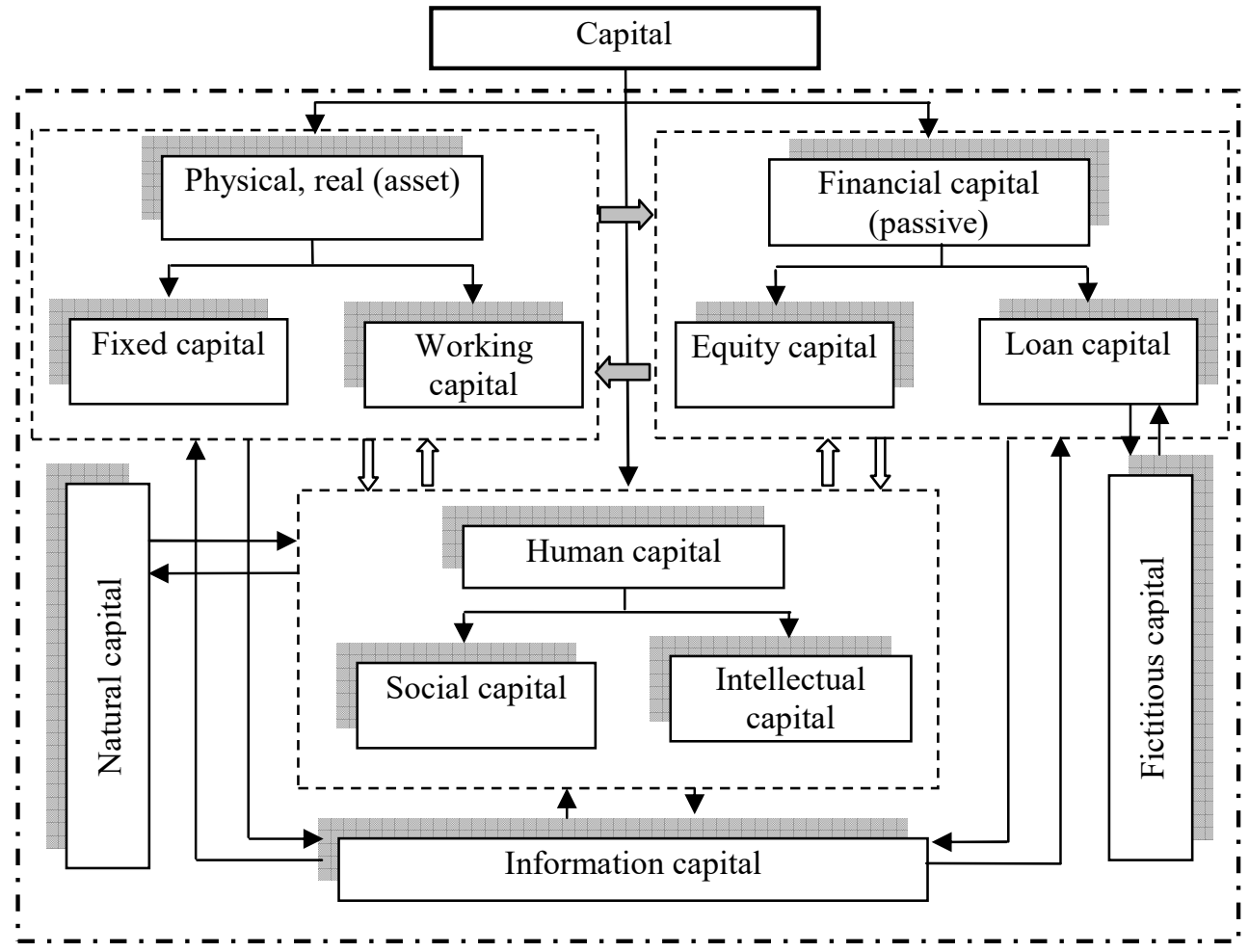

Fig. 2. The relationship of the components of the definition of «capital».

Further research showed that national theory and practice are deprived of theoretical justification and term content both in the scientific literature and in the normative and legislative documents of most components of the definition of «capital» presented in Figure 2.

After analyzing the scientific literature, we suggest we formulate the definitions of capital components within the existing accounting and analytical system of the Russian economy that meet modern business conditions for their further use in accounting practice (Table 3), as well as the definition of additional components of the definition of «capital», which must be considered in a comprehensive manner in the light of the modern development of Russian accounting science and practice (Table 4). 
Table 3. Systematization of the terminology of the components of the definition of «capital» within the existing accounting and analytical system of the Russian economy.

\begin{tabular}{|l|l|}
\hline \multicolumn{1}{|c|}{$\begin{array}{c}\text { Component of the definition of } \\
\text { «capital» }\end{array}$} & \multicolumn{1}{|c|}{ Definition } \\
\hline Physical, real (asset) & $\begin{array}{l}\text { It presents a set of assets of an enterprise, through } \\
\text { which production process of an economic entity is } \\
\text { carried out. }\end{array}$ \\
\hline Wixed capital & $\begin{array}{l}\text { A certain total value that an entrepreneur has at his } \\
\text { disposal and directs it to obtain economic benefit and } \\
\text { satisfy his economic interests. Fixed capital is used for } \\
\text { a long time and is capable of generating income. }\end{array}$ \\
\hline Forking capital & $\begin{array}{l}\text { The value terms of the objects of labor involved } \\
\text { simultaneously in the production process and in the } \\
\text { process of selling products, that is, this is the difference } \\
\text { between current assets and current (short-term) } \\
\text { liabilities of an enterprise, an organization. The value } \\
\text { of working capital reflects the amount of funds that } \\
\text { belong to the enterprise in current assets. }\end{array}$ \\
\hline Equancial capital & $\begin{array}{l}\text { It represents the sources of formation of assets of an } \\
\text { economic entity. }\end{array}$ \\
\hline Loan capital & $\begin{array}{l}\text { The total value of the assets of an economic entity with } \\
\text { the deduction of its liabilities, formed as a result of the } \\
\text { use of fixed and working capital. Sources of equity } \\
\text { capital are: authorized capital stock, reserve capital, } \\
\text { added capital and retained income (uncovered loss). }\end{array}$ \\
\hline & $\begin{array}{l}\text { Part of the financial resources of an economic entity } \\
\text { that are invested in the assets of the latter. They } \\
\text { represent the legal and economic third-party liabilities } \\
\text { of an enterprise. }\end{array}$ \\
\hline
\end{tabular}

Table 4. Systematization of terminology of additional components of the definition of «capital».

\begin{tabular}{|l|l|}
\hline \multicolumn{1}{|c|}{$\begin{array}{c}\text { Component of the } \\
\text { definition of «capital» }\end{array}$} & \multicolumn{1}{|c|}{ Definition } \\
\hline Human capital & $\begin{array}{l}\text { A certain health reserve, knowledge, skills, abilities, } \\
\text { motivations formed as a result of investment activities and } \\
\text { accumulated by a person, are used in the production process, } \\
\text { increasing its efficiency. }\end{array}$ \\
\hline Social capital & $\begin{array}{l}\text { Part of social relations between employees of an enterprise for } \\
\text { the exchange of information and experience, bringing } \\
\text { additional income and thereby increasing the efficiency of the } \\
\text { production process. }\end{array}$ \\
\hline Intellectual capital & $\begin{array}{l}\text { Economic relations aimed at achieving effective management, } \\
\text { use and reproduction of intellectual resources in order to } \\
\text { generate additional income in the process of economic } \\
\text { development of an enterprise. }\end{array}$ \\
\hline Information capital & $\begin{array}{l}\text { Total information being of great interest to an economic } \\
\text { entity, is stored on tangible media and databases, information } \\
\text { systems and technologies. On the one hand, it is a product of } \\
\text { human capital, and on the other hand, it is a mechanism for } \\
\text { generalizing components of intellectual capital. }\end{array}$ \\
\hline Natural capital & $\begin{array}{l}\text { The totality of representatives of flora and fauna, products of } \\
\text { their waste products, minerals and other natural resources that } \\
\text { can influence the results of economic entities. }\end{array}$ \\
\hline Fictitious capital & $\begin{array}{l}\text { The conversion of debt into an object of treaty relations, } \\
\text { depending on the expected revenue position, inflation, interest } \\
\text { rates. }\end{array}$ \\
\hline
\end{tabular}


In the framework of the modern development of economic science, there has been a significant expansion of the components of capital as an economic category. In the last decade, the concept of human capital has been intensively used by world science, which has appreciated the role of intellectual activity, has ascertained the need and high efficiency of investments in human capital under the condition of a high level of social component, since human capital is formed not only in the scientific and educational environment, but also in healthcare system and other areas that determine the living conditions of a person.

The knowledge, qualifications, professional skills accumulated by a person are considered as an equal type of capital along with its traditional types. At the same time, human capital is the main driving factor in the interaction and reproduction of business, government and society, which needs investment.

In the context of the information economy, the value of information capital increases sharply, information mobility of production resources and the flexibility of institutional structures increase, and e-government and network communities are formed. The most important area of investment is the reproduction of information, scientific knowledge, human capital and information infrastructure. Consequently, information capital can be considered as an economic and accounting category exclusively in conjunction with human capital. Without a high level of development of human capital, information capital as an economic resource becomes useless.

The current economic conditions are characterized by an expedition of the processes of concentration and centralization of capital, which inevitably entails the separation of capital property from capital function. Such a separation has led to the formation of a completely new component of capital - fictitious capital, the amount of which contributes to a change in the total expenditure of an economic entity.

The category of fictitious capital today, as never before, has independent significance for modern economic science. This is the antipode of real capital, characterized by a productive nature of functioning. Fictitious capital is a collection of securities circulating on the stock market and participating in the reproduction process, since securities, as a rule, transform savings into real investments.

Since fictitious capital is a combination of socially significant benefits that have both positive and negative external effects, the regulation of their production and consumption should be aimed at minimizing possible damage. Thus, the study and further development of promising forms of development of fictitious capital of the Russian economy is in demand in the context of increasing the value of the results of strategically-oriented selective planning, the shortage of qualitatively new ideas that provide investment filling of the process of establishment and development of bridgeheads of the new economy, reliance on the internal resources of the economy system.

The development of information technology and the ongoing integration processes in the accounting systems of business entities do not allow to put an end to research on the nature of capital and its components. Further development is being carried out in the field of theoretical and methodological provisions for the automation of accounting technologies. Therefore, the term content of capital will continue to be adjusted to ensure the process of improvement and development of capital, which will provide a constant increase in the amount and quality of life benefits.

The realization of the terminology of capital and the way it is reflected in accounts is quite important for both investors and creditors. In addition, a certain clarity in the term content, as well as an understanding of the fundamental equation and its variations, are of particular importance for the purpose of economic analysis. 


\section{References}

1. S. Orlova, J.T. Harper, L. Sun, Journal of Economic and Busines (2020) doi:10.1016/j.jeconbus.2020.105905

2. P. Lewin, N. Cachanosky, Journal of Economic Behavior \& Organization 150, 423-431 (2018) doi:10.1016/j.jebo.2018.01.024

3. E.P. Fenichel, J. Abbott, S. Do Yun, Handbook of Environmental Economics 4, 85142 (2018) doi:10.1016/bs.hesenv.2018.02.002

4. A. Missemer, Ecological Economics 143, 90-96 doi:10.1016/j.ecolecon.2017.07.011

5. H. Daly, Ecosystem Services (2020) doi:10.1016/j.ecoser.2019.101051

6. M. Barbi, S. Mattioli, Research in International Business and Finance 49, 1-12 (2019) doi:10.1016/j.ribaf.2019.02.005

7. M. Wasif Zafar, S. Anees Haider Zaidi, N.R. Khan, F. Mehmood Mirza, F. Hou, S. Ali Ashiq Kirmani, Resources Policy 63 (2019) doi:10.1016/j.resourpol.2019.101428

8. M. Sabatino, International Review of Economics\&Finance 61, 355-367 (2019) doi:.10.1016/j.iref.2019.02.011

9. A. Habersetzer, S. Grezes-Burcher, R. Boschma, H. Mayer, Journal of Rural Studies 651, 143-151 (2019) doi:10.1016/j.jrurstud.2018.10.009

10. I. Hasan, Q. He, H. Lu, Journal of International Money and Finance (2020) doi:10.1016/j.jimonfin.2020.102162

11. J. Barrena-Martinez, L. Cricelli, E. Ferrandiz, M. Greco, M. Grimaldi, Journal of Business Research (2019) doi:10.1016/j.jbusres.2019.10.029

12. F. Sardo, Z. Serrasqueiro, H. Alves, International Journal of Hospitality Management 75, 67-74 (2018) doi:10.1016/j.ijhm.2018.03.001

13. C.-C. Lee, C.-K. Lin, Asia Pacific Management Review 24, 124-139 (2019) doi:10.1016/j.apmrv.2018.01.006

14. M. Khalifa, H. Zouaoui, H. Ben Othman, K. Hussainey, Journal of International Accounting, Auditing and Taxation 36, (2019) doi:10.1016/j.intaccaudtax.2019.100272

15. C. Karuna, Pacific Basin Finance Journal 55, 161-168 (2019) doi:10.1016/j.pacfin.2019.03.001 